\title{
VEGETATION GROWTH, YIELD AND YIELD QUALITY OF POTATO CROP AND SOIL PROPERTIES RESPONSE TO BENTONITE APPLICATION
}

\author{
R. A. Mohamed ${ }^{(1)}$, R. A. Drar ${ }^{(2)}$ and M.M. Abd-El-Ghani ${ }^{(2)}$ \\ (1) Horticulture Research Institute. Agriculture Research center Giza, Egypt. \\ (2) Soil, Water and Environment Res. Inst.
}

Received: Apr. 20, 2017

Accepted: Apr. 29,2017

\begin{abstract}
Two field experiments were conducted during the winter season 2014-2015 and 2015 - 2016 at Experimental Station Farm, Horticultural Research Station, Behera Governorate, Egypt, to study the influence of two bentonite types (black and brown) and rates of their application $(0,5,10,15$ ton/fed) on some vegetative growth characters, yield and its components of potato plants (Sponta c.v.) and some physical and chemical characteristics of sandy soil. The results indicated that vegetative growth characters (plant height, branch number/ plants, fresh and dry weight/plant) were significantly increased by addition of black bentonite as compared to brown one. Also yield and yield component (tuber yield/plant, number of tuber/plant, weight of one tuber and tuber yield/fed) were higher due to application of black bentonite compared to brown one. Three application rates $(0,5,10,15$ ton/fed) significantly increased all vegetative character, yield and its component. The highest increase were obtained for application of 15 ton/fed bentonite. The interaction effect between two bentonite types was significant. The highest increases in vegetative growth, yield and its components were obtained for application of 15 ton/fed black bentonite. There were no significant difference between two bentonite types on chemical contents of foliage contents ( $N, P$ and $K)$ and tuber contents (starch, protein $N, P$, and $K$ ). Application rates (5, 10 and 15) all significantly increased chemical, $N, P$ and $K$ contents of foliage and tuber. The highest increase were obtained by application of 15 ton/fed bentonite. The interaction between two bentonite types and their rates of application reflected positive effect in all chemical contents of foliage and tuber. The highest increased was obtained by application of 15 ton/fed black tafla.

Application of black bentonite had significant effect on soil E.C., CEC, organic matter, water holding capacity as compared to brown bentonite. Rates of (0,5, 10, 15 ton/fed) significantly increased all studied chemical and physical soil characters. The interaction between two bentonite types and its rates of application reflected positive effects on all studied characters of soil. The highest effect was obtained due to application of 15 ton/fed black bentonite.
\end{abstract}

Key words: Sand, Soil, Potato, Bentonite, Nutrients available and Tubers yield.

\section{INTRODUCTION}

Potato (Solanumtuberosum) is one of the most important food crops in the world. In rank following wheat, maize and rice in the world (FAO 2011). Potato is grown of land in 150 countries in the global with estimated annual production of 324 million ton. It is the second vegetable crop after tomato according to the cultivation area and the most important export crop. As a result, potato cultivation is expanding rapidly in Egypt with corresponding increase in consumption.
Potato is the rich source of starch, vitamin, $\mathrm{C}, \mathrm{B}$ and minerals. It contains about 20.0 carbohydrate, 2.190 protein, $0.3 \%$ fat, $1.1 \%$ fiber and 0.9 ash (kumaret al. 2012). According to the methods described by data were recorded in Tabe (1). Potato cultivation extended to newly reclamation soil. Most of this soil is sandy and having poor hydro-physical and nutritional properties such as low water holding capacity, low cations exchange capacity, low contains of available nutrients and well as 
poor structure and low level of organic matter. Using bentonite is the most important soil conditioners it may be found in any volcanic area near the sea shore. ElSherif (1987) reported that chemical composition of tafla deposits contain bentonite, he found that the majority of clay mineral in bentonite were montmorillonite.

Utilization of bentonite for high sand soil reclamation is generally widely spread in many countries with developed agriculture. Bentonite acts as soil sorbent mainly during process of humification of sandy soil by bonding sand grains and organic colloids and protection against fast percolation of water through the soil, increase significantly reduction wash out of fertilizers and chemical matters which means reduced pollution of environment is the accompanying effect (Fernandez- Nava et al., 2011).

Tawfiq (2009) stated that bentonite decrease decomposition rate of organic substance and improve humification coefficient, so it can raise the quantity of organic matter, improve the sandy soil fertility, growth yield and chemical composition of plant. It has reported that addition of bentonite to soil improve water holding capacity and consequently improve water and nutrients supply to plants and enhance crop growth and yield (Qu et al. 2009). Noble et al. (2004) showed that applying bentonite as soil conditioner effective improved of forage sorghum. Aghdak et al. (2010) pointed out that highest growth yield parameters of snap been were observed by using bentonite. The same trend was found by Reguieg et al. (2012) and Hassan and Mahmoud (2013) who showed that addition of bentonite increased percentage of morphological vegetative growth parameter and seed yield of faba bean and corn plants. In a more recent study by Shaheen et al. (2013) and Yousef
(2013) additional evidences were provided to show that application of bentonite to sandy soil had positive effect on all measured characteristics of vegetative growth, tuber yield and tuber quality of potato plants.

The aime this work is to study the effect of two bentonite types and their rates yield and some properties sandy soil.

\section{MATERIALS AND METHODS}

During two consecutive wither seasons of 2014-2015 and 2015-2016 two field experiments were conducted at the Experimental Station Farm, Horticultural Research Institute, Behiera Governorate, Egypt, to study the effect of two types of bentonite (black and brown) at different rates of application (0, 5, 10 and 15 ton/fed) on the yield of potato plant (Sponta cultivar) yield, and its quality,as well as, sandy soil properties. A sample at $30 \mathrm{~cm}$ depth of the studied soil were collected, air dried, ground, passed through a $2 \mathrm{~mm}$ sieve. Some physical and chemical analysis as well as soil available NPK were carried out according to the methods described by Black (1965) and Page (1982). The obtained data were recorded in table (1). Bentonite provided for Mining and Natural fertilizers, Giza, Egypt. The physical and chemical composition of bentonite, are given in Table (2).

Bentonite type represent the main plot, where replicated on rate of the used tubes ob Bentonite, the sup blots, be for planting. The field was arranged as split-plot design with 4 replication. The main plot factor was rate of application $(0,5,10$ and 15 ton/fed). Bentonite was mixed with soil surface layer $(0-20 \mathrm{~cm})$. For all experiment plots, the full amount of calcium super-phosphate $(16 \%$ $\left.\mathrm{P}_{2} \mathrm{O}_{5}\right)$ at rate of $75 \mathrm{~kg} \mathrm{P}_{2} \mathrm{O}_{5} / \mathrm{fed}$ are added at time of final land preparation. The potato tubers of Sponta cultivar . 
Table 1. Some physical and chemical properties of the studied soil.

\begin{tabular}{|c|c|c|}
\hline \multirow{2}{*}{$\begin{array}{l}\text { Soil characteristics } \\
\text { Particle size distribution }\end{array}$} & Season I & Seasonll \\
\hline & & \\
\hline - Coarse sand & 66.5 & 67.2 \\
\hline - Fine sand & 29.2 & 30.3 \\
\hline - Silt & 2.2 & 2.4 \\
\hline - Clay & 2.1 & 2.1 \\
\hline - Texture class & Sandy & Sandy \\
\hline O.M (\%) & 0.22 & 0.25 \\
\hline $\mathrm{CaCO} 3(\%)$ & 1.7 & 1.81 \\
\hline Field capacity & 12.1 & 13.2 \\
\hline Cation exchange capacity (c mole/kg soil) & 4.3 & 4.1 \\
\hline $\mathrm{pH}(1: 2.5$ soil /water ratio) & 7.75 & 7.81 \\
\hline $\mathrm{EC} \mathrm{dSm}{ }^{-1}$ (soil past extract) & 0.43 & 0.49 \\
\hline Soluble cations (mmole/L) & & \\
\hline$-\mathrm{Ca}^{+2}$ & 1.14 & 1.24 \\
\hline$-\mathrm{Mg}^{+2}$ & 1.67 & 1.57 \\
\hline$-\mathrm{Na}^{+1}$ & 1.28 & 1.18 \\
\hline$-\mathrm{K}^{+1}$ & 0.17 & 0.27 \\
\hline Soluble anion(mmole/L) & & \\
\hline$-\mathrm{CO}_{3}^{-2}$ & 0.00 & 0.00 \\
\hline$-\mathrm{HCO}_{3}^{-1}$ & 2.30 & 2.10 \\
\hline$-\mathrm{Cl}^{-1}$ & 1.41 & 1.61 \\
\hline$-\mathrm{SO}_{4}^{-2}$ & 0.64 & 0.64 \\
\hline Available nutrients (mg/kg soil) & & \\
\hline$-N$ & 19.5 & 21.2 \\
\hline$-P$ & 8.2 & 8.8 \\
\hline$-\quad K$ & 38.5 & 40.1 \\
\hline
\end{tabular}

Table 2. Chemical analysis of bentonite.

\begin{tabular}{|c|c|c|c|c|c|c|c|c|c|c|c|c|}
\hline $\begin{array}{c}\text { Bentonite } \\
\text { types }\end{array}$ & $\mathrm{SiO}_{3}$ & $\mathrm{Al2O} 3$ & $\mathrm{~N}_{2} \mathrm{O}_{3}$ & $\mathrm{Fe}_{2} \mathrm{O}_{3}$ & $\mathrm{MgO}$ & $\mathrm{CaO}$ & $\mathrm{K}_{2} \mathrm{O}$ & $\mathrm{TiO}_{2}$ & $\mathrm{Mn}$ & $\mathrm{pH}$ & $\begin{array}{c}\text { C.E.C } \\
(\mathrm{cmol} / \mathrm{kg})\end{array}$ & $\begin{array}{c}\text { Water } \\
\text { holding } \\
\text { capacity } \\
(\%)\end{array}$ \\
\hline Black & 56.10 & 15.50 & 2.99 & 1.17 & 7.18 & 1.07 & 1.21 & 0.56 & 0.06 & 7.48 & 73 & 131 \\
\hline Brown & 60.30 & 19.30 & 1.70 & 0.40 & 2.70 & 0.08 & 0.20 & 0.60 & 0.10 & 7.61 & 69 & 115 \\
\hline
\end{tabular}

Were sown under sandy soil condition on drip irrigation ridges of $50 \mathrm{~cm}$ width, $10.5 \mathrm{~m}$ length and $25 \mathrm{~cm}$ apart on one side of the ridge. Each experimental sub-plot consisted of $10 \mathrm{~m} 2$ ( 2 line $\times 10.5$ length $\times 0.5 \mathrm{~m}$ apart). Tubers were planted at $10 \mathrm{~cm}$ depth and 25 $\mathrm{cm}$ apart within the row. Ammonium sulphate $(20.5 \% \mathrm{~N})$ at the rate of $200 \mathrm{~kg}$
$\mathrm{N} / \mathrm{fed}$ and potassium sulphate at rate of 100 $\mathrm{kg} \mathrm{K}_{2} \mathrm{O} / \mathrm{fed}$ were added through drip irrigation system. At 90 days 7 plants randomly selected were taken from each sub-plot to measured plant height, branch number/plant, fresh and dry weight plant. 
At harvesting stage, tuber yield characteristic which include tuber number/ plant, tuber weight /plant (g), tuber yield ton/fed average one tuber weight was recorded.

In addition samples from tuber were randomly taken from each plot, dried at $70 \mathrm{C}^{\circ}$, then grinded to determine chemical qualities. Total nitrogen percentage was determined using modified micro Kjeldahl method and phosphorus was determined using the colorimeter method using spectrophotometer according Cottenie et al. (1982). While potassium percentage was measured using flame photometer method as described by Chapman Pratt (1982). Tuber dried samples were also used to determine the content starch and protein according the method described by AOAC (1990).

\section{RESULTS AND DISCUSSION Vegetative Growth:}

Data presented in Table 3 indicated that, the vegetative growth characters of potato i.e. plant high, plant branch number, foliage fresh and dry weight / plant of application black bentonite were significantly higher than that obtained from the application of brown ones in both studied seasons. This is may be due to that soil C.E.C., water holding capacity and field capacity with application of black bentonite were higher compared with the same treatments of brown ones (Table 1). Enhance soil C.E.C., water holding capacity of black bentonite significantly affected on plant growth through good water and nutrient supply for plant.

Data in Table 3 showed that the application rate $(5,10$ and 15 ton/fed) of bentonite significantly increased all vegetative plant growth compared to control. There was asignificant difference increase among different rate of application. The highest rate of bentonite ( 15 ton/fed) gave the highest values of all vegetative growth characters in both seasons. The enhancing effect of applied bentonite on plant growth may be attributed to beneficial effect of increasing rates of application on soil C.E.C., water retention and available nutrients. This finding agreed with obtained by (Hossam and Abdel Wahab 2013) and (El-Dardiry and Abdel-Hady 2015).

The interaction effect between two types and rate of application on plant growth of potato plant reflected significantly differences for all vegetative growth (Table $3)$. The application of black bentonite at rate $15 /$ ton/fed gave the highest plant height, branch number/plant, fresh and dry weight/plant.

\section{Yield and its components:}

Regarding to comparison between the effect of two bentonite types on yield and yield components of potato (Table 4) data indicated that the effect of black bentonite on yield and yield components of potato significantly higher than that obtained with brown ones. The superiority of black bentonite may be due to that its higher cation exchange capacity (C.E.C) and water holding capacity (Table 2 ) and consequently improve water and nutrient supply to plant and also, enhance crop yield and its component ( $\mathrm{Qu}$ et al. 2009). Moreover Shaheen et al. (2013) and Yossef (2013) reported that apply bentonite at different rates effectively improved yield and yield component of potato plants.

The effect of different application rates of bentonite on yield and yield components are presented in Table 4. Application of bentonite at different rate gained a clear enhancement in yield and yield component on two seasons as compared to control. There was a significant difference increase among different rates of bentonite (Table 4). The highest rate of bentonite (15 ton/fed) gave the highest values of yield and yield components of potato plant followed by application of 10 ton/fed. The obtained results are in good accordance with data obtained by (Zelalen 2009, Shahzad Jammati et al. 2010, Shaheen et al. 2013 and Yousse 2013). 
Vegetation growth, yield and yield quality of potato crop and soil .............

Table 3. Effect of bentonite types and rates of application on growth characters of potato plant.

\begin{tabular}{|c|c|c|c|c|c|c|c|c|c|}
\hline \multirow[b]{2}{*}{$\begin{array}{l}\text { Bentonite } \\
\text { type }\end{array}$} & \multirow[b]{2}{*}{$\begin{array}{l}\text { Application } \\
\text { rate ton/f }\end{array}$} & \multicolumn{4}{|c|}{$2014-2015$} & \multicolumn{4}{|c|}{$2015-2016$} \\
\hline & & $\begin{array}{l}\text { Plant } \\
\text { height } \\
\text { (cm) }\end{array}$ & $\begin{array}{l}\text { Branch } \\
\text { No. } \\
\text { /plant }\end{array}$ & $\begin{array}{c}\text { Dry } \\
\text { weight } \\
\text { /plant } \\
\text { (g) }\end{array}$ & $\begin{array}{c}\text { Fresh } \\
\text { weight } \\
\text { /plant } \\
\text { (g) }\end{array}$ & $\begin{array}{c}\text { Plant } \\
\text { height } \\
(\mathrm{cm})\end{array}$ & $\begin{array}{l}\text { Branch } \\
\text { No. } \\
\text { /plant }\end{array}$ & $\begin{array}{c}\text { Dry } \\
\text { weight } \\
\text { /plant } \\
\text { (g) }\end{array}$ & $\begin{array}{c}\text { Fresh } \\
\text { weight } \\
\text { /plant (g) }\end{array}$ \\
\hline \multirow{4}{*}{ Black } & 0 & 56.36 & 3.67 & 405.79 & 60.17 & 53.11 & 3.40 & 377.59 & 61.18 \\
\hline & 5 & 57.10 & 5.19 & 431.56 & 64.07 & 54.53 & 4.88 & 430.43 & 64.74 \\
\hline & 10 & 65.10 & 6.67 & 547.99 & 70.80 & 64.58 & 6.56 & 535.43 & 71.62 \\
\hline & 15 & 74.13 & 6.93 & 567.06 & 75.58 & 73.10 & 6.19 & 570.27 & 76.12 \\
\hline \multicolumn{2}{|c|}{ Mean } & 63.17 & 5.62 & 488.10 & 67.66 & 61.33 & 5.26 & 478.43 & 68.42 \\
\hline \multirow{4}{*}{ Brown } & 0 & 52.24 & 3.38 & 388.94 & 58.56 & 51.40 & 3.20 & 377.25 & 57.81 \\
\hline & 5 & 56.47 & 5.10 & 422.59 & 63.00 & 54.11 & 4.13 & 434.72 & 64.86 \\
\hline & 10 & 65.15 & 5.89 & 532.59 & 68.85 & 63.17 & 5.23 & 528.51 & 69.88 \\
\hline & 15 & 76.17 & 6.53 & 539.39 & 71.11 & 73.98 & 6.43 & 544.85 & 72.80 \\
\hline \multicolumn{2}{|c|}{ Mean } & 62.51 & 5.23 & 470.88 & 65.38 & 60.67 & 4.75 & 471.33 & 66.34 \\
\hline \multirow{4}{*}{$\begin{array}{c}\text { Means of } \\
\text { rate }\end{array}$} & 0 & 54.30 & 3.53 & 397.37 & 59.37 & 52.26 & 3.30 & 377.42 & 59.50 \\
\hline & 5 & 56.79 & 5.15 & 427.08 & 63.54 & 54.32 & 4.51 & 432.58 & 64.80 \\
\hline & 10 & 65.13 & 6.28 & 540.29 & 69.83 & 63.88 & 5.90 & 531.97 & 70.75 \\
\hline & 15 & 75.15 & 6.73 & 553.23 & 73.35 & 73.54 & 6.31 & 557.56 & 74.46 \\
\hline \multirow{3}{*}{ L.S.D 0.05} & Type & 0.68 & 0.20 & 6.72 & 0.26 & 0.30 & 0.17 & 4.77 & 0.26 \\
\hline & Rate & 2.20 & 0.26 & 8.68 & 0.47 & 0.49 & 0.23 & 6.63 & 0.51 \\
\hline & Type*Rate & 1.80 & 0.36 & 12.20 & 0.66 & 0.70 & 0.05 & $9 . .3$ & 0.72 \\
\hline
\end{tabular}

The interaction effect between two bentonite types and rates of its application (Table 4) the highest increase in growth character (plant height, branch number/plant, fresh and dry weight /plant) and tuber yield /plant, tuber weight, number of tube / plant and tuber yield /fed were significantly obtained with application of 15 ton/fed of black one.

\section{Chemical composition:}

Table 5 show the effect of two bentonite types and application rates on $\mathrm{N}, \mathrm{P}$ and $\mathrm{K}$ contents of potato foliage there is no significant differences between two bentonite types on contents of three elements.

Application rates 5, 10 and 15 ton/fed significantly increased the concentration of $\mathrm{N}$ and $\mathrm{K}$ contents of potato foliage, the highest increase was obtained by application of 15ton/fed. The interaction between two bentonite types and their application (Table 5) revealed that no significant between two bentonite types and rates of application on $\mathrm{N}, \mathrm{P}$ and $\mathrm{K}$ contents of foliage.

Results presented in Table 6 indicated that no significant difference between bentonite types on starch, protein, N, P and 
$\mathrm{K}$ tuber contents. With respect to the effect of rates of application (5, 10 and 15 ton/fed) all rates significantly affected on starch, protein, $\mathrm{N}$ and $\mathrm{K}$ tuber contents. The highest increase were obtained by application of 15 ton/fed. Interaction between types and rate of application had no significant effect on starch, protein, $\mathrm{N}, \mathrm{P}$ and $\mathrm{K}$ tuber contents. These results supported by Aghdak et al. (2010) on snap bean, Anas et al. (2009) on peanut Shaheen et al. (2013) and Yousef (2013) on potato.
Improving in nutrient contents of potato as a result of bentonite application is due that bentonite increase both of retention and generation a sorption complex of bound sandy grain and organic colloids followed with prevent water and available nutrients (macro and micro) to percolate far away from the root zone distribution. Increasing soluble nutrients in rooting zone caused an increase of its absorption by plants, consequently increased the ability of plant roots to uptake more elements in its plant tissues (Ali et al. 2001 and Gan 2005).

Table 4. Effect of bentonite types and rates of application on the yield and component of potato plant.

\begin{tabular}{|c|c|c|c|c|c|c|c|c|c|}
\hline \multirow[b]{2}{*}{$\begin{array}{l}\text { Bentonite } \\
\text { type }\end{array}$} & \multirow[b]{2}{*}{$\begin{array}{l}\text { Application } \\
\text { rate ton/f }\end{array}$} & \multicolumn{4}{|c|}{$2014-2015$} & \multicolumn{4}{|c|}{$2015-2016$} \\
\hline & & 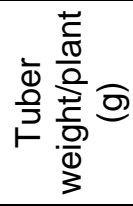 & 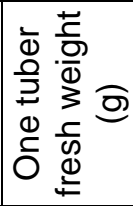 & 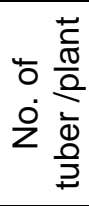 & 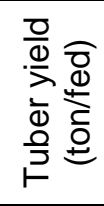 & 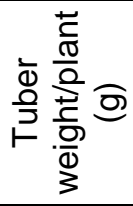 & 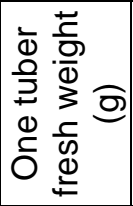 & 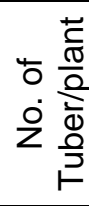 & 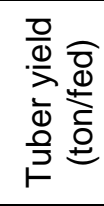 \\
\hline \multirow{4}{*}{ Black } & 0 & 605.52 & 118.27 & 5.12 & 10.25 & 717.31 & 119.16 & 6.20 & 12.19 \\
\hline & 5 & 763.30 & 122.78 & 6.22 & 12.97 & 804.14 & 122.00 & 6.59 & 13.95 \\
\hline & 10 & 804.59 & 124.30 & 6.47 & 13.87 & 849.89 & 124.98 & 6.80 & 14.90 \\
\hline & 15 & 904.24 & 128.24 & 7.09 & 15.45 & 938.56 & 127.74 & 7.34 & 16.60 \\
\hline \multicolumn{2}{|c|}{ Mean } & 769.41 & 123.40 & 6.23 & 13.14 & 827.48 & 123.47 & 6.73 & 14.41 \\
\hline \multirow{4}{*}{ Brown } & 0 & 706.74 & 119.72 & 5.92 & 10.50 & 726.68 & 118.96 & 6.11 & 11.30 \\
\hline & 5 & 787.27 & 121.21 & 6.42 & 12.38 & 800.51 & 120.34 & 6.65 & 13.11 \\
\hline & 10 & 821.99 & 123.34 & 6.66 & 13.31 & 840.65 & 124.52 & 6.75 & 14.29 \\
\hline & 15 & 909.24 & 126.35 & 7.16 & 14.50 & 926.35 & 126.57 & 7.31 & 15.30 \\
\hline \multicolumn{2}{|c|}{ Mean } & 806.31 & 122.66 & 6.54 & 12.67 & 823.55 & 122.60 & 6.71 & 13.50 \\
\hline \multirow{4}{*}{$\begin{array}{l}\text { Means } \\
\text { of rate }\end{array}$} & 0 & 656.13 & 119.00 & 5.52 & 10.38 & 722.00 & 119.06 & 6.16 & 11.75 \\
\hline & 5 & 775.29 & 122.00 & 6.32 & 12.68 & 802.33 & 121.17 & 6.62 & 13.53 \\
\hline & 10 & 813.29 & 123.82 & 6.57 & 13.59 & 845.27 & 124.75 & 6.78 & 14.60 \\
\hline & 15 & 906.74 & 127.30 & 7.13 & 14.98 & 932.46 & 127.16 & 7.33 & 15.95 \\
\hline \multirow{3}{*}{ L.S.D $D_{0.05}$} & Type & 9.26 & 0.70 & 0.08 & 0.15 & n.s & 0.35 & 0.02 & 0.25 \\
\hline & Rate & 10.63 & 0.80 & 0.11 & 0.18 & 3.34 & 0.33 & 0.11 & 0.30 \\
\hline & Type ${ }^{\star}$ Rate & 6.16 & 1.10 & 0.14 & 0.25 & 4.55 & 0.93 & 0.29 & 0.26 \\
\hline
\end{tabular}


Vegetation growth, yield and yield quality of potato crop and soil .............

Table 5. Effect of bentonite types and rates of application on NPK contents(\%) of Potato foliage

\begin{tabular}{|c|c|c|c|c|c|c|c|}
\hline \multirow{2}{*}{$\begin{array}{l}\text { Bentonite } \\
\text { type }\end{array}$} & \multirow{2}{*}{$\begin{array}{l}\text { Application } \\
\text { rate ton/f }\end{array}$} & \multicolumn{3}{|c|}{$2014-2015$} & \multicolumn{3}{|c|}{$2015-2016$} \\
\hline & & $\mathrm{N}$ & $P$ & K & $\mathrm{N}$ & $P$ & $\mathrm{~K}$ \\
\hline \multirow{4}{*}{ Black } & 0 & 2.20 & 0.32 & 2.20 & 2.30 & 0.31 & 2.30 \\
\hline & 5 & 2.80 & 0.35 & 2.90 & 2.75 & 0.34 & 3.10 \\
\hline & 10 & 3.22 & 0.34 & 3.50 & 3.15 & 0.33 & 3.60 \\
\hline & 15 & 3.33 & 0.34 & 3.60 & 3.45 & 0.33 & 3.50 \\
\hline \multicolumn{2}{|c|}{ Mean } & 2.89 & 0.34 & 3.05 & 2.91 & 0.33 & 3.13 \\
\hline \multirow{4}{*}{ Brown } & 0 & 2.15 & 0.35 & 2.30 & 2.40 & 0.36 & 2.20 \\
\hline & 5 & 2.71 & 0.34 & 2.90 & 2.90 & 0.35 & 2.70 \\
\hline & 10 & 3.11 & 0.38 & 3.36 & 3.44 & 3.60 & 3.40 \\
\hline & 15 & 3.41 & 0.33 & 3.50 & 3.49 & 3.70 & 3.60 \\
\hline \multicolumn{2}{|c|}{ Mean } & 2.85 & 0.35 & 3.02 & 3.06 & 2.00 & 2.98 \\
\hline \multirow{4}{*}{$\begin{array}{c}\text { Means of } \\
\text { rate }\end{array}$} & 0 & 2.18 & 0.34 & 2.25 & 2.35 & 0.34 & 2.25 \\
\hline & 5 & 2.76 & 0.35 & 2.90 & 2.83 & 0.35 & 2.90 \\
\hline & 10 & 3.17 & 0.36 & 3.43 & 3.30 & 1.97 & 3.50 \\
\hline & 15 & 3.37 & 0.34 & 3.55 & 3.47 & 2.02 & 3.55 \\
\hline \multirow{3}{*}{ L.S.D $D_{0.05}$} & Type & n.s & n.s & n.s & n.s & n.s & n.s \\
\hline & Rate & 0.22 & n.s & 0.26 & 0.21 & n.s & 0.35 \\
\hline & Type*Rate & n.s & n.s & n.s & n.s & n.s & n.s \\
\hline
\end{tabular}

Table 6. Effect of bentonite types and rates of application on tuber starch, protein and NPK contents.

\begin{tabular}{|c|c|c|c|c|c|c|c|c|c|c|c|}
\hline \multirow{2}{*}{$\begin{array}{l}\text { Bentonite } \\
\text { type }\end{array}$} & \multirow{2}{*}{$\begin{array}{l}\text { Application } \\
\text { rate ton/f }\end{array}$} & \multicolumn{5}{|c|}{$2014-2015$} & \multicolumn{5}{|c|}{$2015-2016$} \\
\hline & & $\begin{array}{c}\text { Starch } \\
(\%)\end{array}$ & $\begin{array}{l}\text { Protein } \\
(\%)\end{array}$ & $\begin{array}{l}N \\
(\%)\end{array}$ & $\begin{array}{c}P \\
(\%)\end{array}$ & $\begin{array}{c}\mathrm{K} \\
(\%)\end{array}$ & $\begin{array}{c}\text { Starch } \\
(\%)\end{array}$ & $\begin{array}{c}\text { Protein } \\
(\%)\end{array}$ & $\begin{array}{c}N \\
(\%)\end{array}$ & $\begin{array}{c}P \\
(\%)\end{array}$ & $\begin{array}{l}\mathrm{K} \\
(\%)\end{array}$ \\
\hline \multirow{4}{*}{ Black } & 0 & 71.80 & 11.30 & 2.10 & 0.39 & 1.18 & 72.90 & 11.10 & 1.90 & 0.36 & 1.20 \\
\hline & 5 & 74.20 & 12.50 & 2.25 & 0.39 & 1.33 & 75.10 & 12.27 & 2.30 & 0.38 & 1.45 \\
\hline & 10 & 76.10 & 13.60 & 2.53 & 0.42 & 1.55 & 76.30 & 14.40 & 2.60 & 0.41 & 1.63 \\
\hline & 15 & 77.50 & 14.90 & 2.58 & 0.42 & 1.72 & 77.10 & 14.90 & 2.70 & 0.45 & 1.78 \\
\hline \multicolumn{2}{|c|}{ Mean } & 74.90 & 13.08 & 2.37 & 0.41 & 1.45 & 75.35 & 13.17 & 2.38 & 0.40 & 1.52 \\
\hline \multirow{4}{*}{ Brown } & 0 & 72.10 & 11.11 & 1.80 & 0.38 & 1.14 & 71.80 & 10.80 & 1.80 & 0.39 & 1.20 \\
\hline & 5 & 74.40 & 13.10 & 2.29 & 0.40 & 1.35 & 73.10 & 12.40 & 2.35 & 0.41 & 1.40 \\
\hline & 10 & 76.60 & 14.21 & 2.49 & 0.40 & 1.53 & 75.80 & 13.50 & 2.51 & 0.42 & 1.81 \\
\hline & 15 & 71.90 & 14.40 & 2.49 & 0.33 & 1.69 & 77.60 & 14.80 & 2.75 & 0.42 & 1.78 \\
\hline \multicolumn{2}{|c|}{ Mean } & 73.75 & 13.21 & 2.27 & 0.38 & 1.43 & 74.58 & 12.88 & 2.35 & 0.41 & 1.55 \\
\hline \multirow{4}{*}{$\begin{array}{l}\text { Means of } \\
\text { rate }\end{array}$} & 0 & 71.95 & 11.21 & 1.95 & 0.39 & 1.16 & 72.35 & 10.95 & 1.85 & 0.38 & 1.20 \\
\hline & 5 & 74.30 & 12.80 & 2.27 & 0.40 & 1.34 & 74.10 & 12.34 & 2.33 & 0.40 & 1.43 \\
\hline & 10 & 76.35 & 13.91 & 2.51 & 0.41 & 1.54 & 76.05 & 13.95 & 2.56 & 0.42 & 1.72 \\
\hline & 15 & 74.70 & 14.65 & 2.54 & 0.38 & 1.71 & 77.35 & 14.85 & 2.73 & 0.44 & 1.78 \\
\hline \multirow{3}{*}{ L.S.D ${ }_{0.05}$} & Type & n.s & n.s & n.s & n.s & n.s & n.s & n.s & n.s & n.s & n.s \\
\hline & Rate & n.s & n.s & n.s & n.s & n.s & n.s & n.s & n.s & n.s & n.s \\
\hline & Type*Rate & n.s & n.s & n.s & n.s & n.s & n.s & n.s & n.s & n.s & n.s \\
\hline
\end{tabular}




\section{Soil content of available macronutrients:}

Data in Table 7 clear that there is no significant difference between brown or black bentonite application on the available $\mathrm{N}, \mathrm{P}$ and $\mathrm{K}$ in soil after harvesting. All rates of bentonite application significantly increased available $\mathrm{N}, \mathrm{P}$ and $\mathrm{K}$ in soil, the highest increase of available $\mathrm{N}$ and $\mathrm{K}$ were obtained under 15 ton/ fed of bentonite. Also the highest available $P$ was obtained with 15 ton/ fed. Statistical analysis clarify that there is no significant difference between application of 10 and 15 ton/ fed. There is no significant effect for interaction between two bentonite types and application rate available soil NPK.

\section{Soil physical and chemical properties soil:}

Data presented in Table $7\left(a_{s} b\right)$ indicate that application of black bentonite significantly increased C.E.C, organic matter, water holding capacity and field capacity compared to brown bentonite. There was no significant effect between two used bentonite on soil pH and E.C.

Table 7. Effect of bentonite types and rates of application on available NPK of sandy soil.

\begin{tabular}{|c|c|c|c|c|c|c|c|}
\hline \multirow{3}{*}{$\begin{array}{l}\text { Bentonite } \\
\text { type }\end{array}$} & \multirow{3}{*}{$\begin{array}{l}\text { Application } \\
\text { rate (ton/f) }\end{array}$} & \multicolumn{3}{|c|}{ 2014-2015 } & \multicolumn{3}{|c|}{$2015-2016$} \\
\hline & & \multicolumn{6}{|c|}{ Available (mg/kg) } \\
\hline & & $\mathrm{N}$ & $P$ & K & $\mathrm{N}$ & $P$ & K \\
\hline \multirow{4}{*}{ Black } & 0 & 25.20 & 9.50 & 38.50 & 26.30 & 8.90 & 38.50 \\
\hline & 5 & 29.10 & 11.20 & 49.30 & 30.20 & 11.10 & 49.30 \\
\hline & 10 & 35.30 & 12.50 & 55.20 & 36.10 & 12.10 & 55.20 \\
\hline & 15 & 38.20 & 13.90 & 59.80 & 39.10 & 13.80 & 59.80 \\
\hline \multicolumn{2}{|c|}{ Mean } & 31.95 & 11.78 & 50.70 & 32.93 & 11.48 & 50.70 \\
\hline \multirow{4}{*}{ Brown } & 0 & 24.90 & 9.80 & 40.10 & 25.40 & 9.20 & 40.10 \\
\hline & 5 & 28.80 & 10.90 & 47.20 & 29.90 & 10.80 & 47.20 \\
\hline & 10 & 35.10 & 11.89 & 54.60 & 36.10 & 11.60 & 54.60 \\
\hline & 15 & 37.50 & 13.60 & 58.90 & 38.90 & 14.20 & 58.90 \\
\hline \multicolumn{2}{|c|}{ Mean } & 31.58 & 11.55 & 50.20 & 32.58 & 11.45 & 50.20 \\
\hline \multirow{4}{*}{$\begin{array}{l}\text { Means of } \\
\text { rate }\end{array}$} & 0 & 25.05 & 9.65 & 39.30 & 25.85 & 9.05 & 39.30 \\
\hline & 5 & 28.95 & 11.05 & 48.25 & 30.05 & 10.95 & 48.25 \\
\hline & 10 & 35.20 & 12.20 & 54.90 & 36.10 & 11.85 & 54.90 \\
\hline & 15 & 37.85 & 13.75 & 59.35 & 39.00 & 14.00 & 59.35 \\
\hline \multirow{3}{*}{ L.S.D $D_{0.05}$} & Type & n.s & n.s & n.s & n.s & n.s & n.s \\
\hline & Rate & 1.26 & 0.81 & 2.41 & 2.10 & 0.72 & 3.10 \\
\hline & Type*Rate & n.s & n.s & n.s & n.s & n.s & n.s \\
\hline
\end{tabular}


Different application rates from 5, 10 and 15 significantly increased soil E.C, C.E.C, O.M, water holding capacity and field capacity compared to control. The highest increased was obtained for application of 15 ton/ fed, where the relative increase \% over control were 72.3 and $73.7,12.5$ and 14.3 , 19.5 and $14.03,18.7$ and $26.4,26.1$ and 27.3 for E.C, C.E.C, O.M, water holding capacity and field capacity in first and second season. Many researchers have shown that addition of bentonite ameliorate the properties of sandy soil by increasing their clay contents. (El-Sherief et al. 1987 and Ben Khalifa 1997).Reguieg and Movly (2007) concluded that addition bentonite to sandy soil increased its E.C, C.E.C, organic matter and water holding capacity, field capacity and total nitrogen. Abdel Hady (2005) and Abdel Hady and Ebtsam 2005 and 2015) found positive significant correlation between bentonite application and soil water content. Addition bentonite to sandy soil had potential effect to improve soil ability to retain water and increased soil available water.

Table 7 (a). Effect of bentonite types and rates of application on physical and chemical properties of soil

\begin{tabular}{|c|c|c|c|c|c|c|c|}
\hline \multirow[b]{2}{*}{$\begin{array}{c}\text { Bentonite } \\
\text { Type }\end{array}$} & \multirow[b]{2}{*}{$\begin{array}{l}\text { Application } \\
\text { rate (ton/f) }\end{array}$} & \multicolumn{6}{|c|}{$2014-2015$} \\
\hline & & $\begin{array}{c}\text { E.C } \\
\left(\mathrm{dS} \mathrm{m}^{-1}\right)\end{array}$ & $\begin{array}{c}\mathrm{pH} \\
(1: 2.5)\end{array}$ & $\begin{array}{c}\text { C.E.C } \\
\mathrm{cmol} / \mathrm{kgsoil}\end{array}$ & $\begin{array}{c}\text { Organic } \\
\text { matter } \\
(\%)\end{array}$ & $\begin{array}{l}\text { Saturation } \\
\text { percent } \\
(\%)\end{array}$ & $\begin{array}{l}\text { Field } \\
\text { capacity } \\
(\%)\end{array}$ \\
\hline \multirow{4}{*}{ Black } & 0 & 1.79 & 7.72 & 4.50 & 0.26 & 20.10 & 11.80 \\
\hline & 5 & 2.30 & 7.81 & 4.90 & 0.31 & 21.20 & 12.90 \\
\hline & 10 & 2.70 & 7.85 & 5.90 & 0.36 & 22.50 & 13.90 \\
\hline & 15 & 3.20 & 7.90 & 6.40 & 0.42 & 24.10 & 19.10 \\
\hline \multicolumn{2}{|c|}{ Mean } & 2.50 & 7.82 & 5.43 & 0.34 & 21.98 & 14.43 \\
\hline \multirow{4}{*}{ Brown } & 0 & 1.83 & 7.85 & 4.40 & 0.28 & 20.20 & 11.60 \\
\hline & 5 & 2.60 & 7.92 & 4.80 & 0.32 & 20.91 & 12.60 \\
\hline & 10 & 3.00 & 7.90 & 5.30 & 0.37 & 21.50 & 13.20 \\
\hline & 15 & 3.40 & 7.80 & 5.90 & 0.43 & 22.80 & 13.80 \\
\hline \multicolumn{2}{|c|}{ Mean } & 2.71 & 7.87 & 5.10 & 0.35 & 21.35 & 12.80 \\
\hline \multirow{4}{*}{$\begin{array}{l}\text { Means of } \\
\text { rate }\end{array}$} & 0 & 1.81 & 7.79 & 4.45 & 0.27 & 20.15 & 11.70 \\
\hline & 5 & 2.45 & 7.87 & 4.85 & 0.32 & 21.06 & 12.75 \\
\hline & 10 & 2.85 & 7.88 & 5.60 & 0.37 & 22.00 & 13.55 \\
\hline & 15 & 3.30 & 7.85 & 6.15 & 0.43 & 23.45 & 16.45 \\
\hline \multirow{3}{*}{ L.S.D $D_{0.05}$} & Type & n.s & n.s & 0.22 & n.s & 0.41 & 0.36 \\
\hline & Rate & 0.22 & n.s & 0.21 & 0.11 & 0.60 & 0.33 \\
\hline & Type*Rate & n.s & n.s & 0.25 & 0.04 & 0.71 & 0.61 \\
\hline
\end{tabular}


Mohamed, et al.,

Table 7 (b). Effect of bentonite types and rates of application on physical and chemical properties of soil

\begin{tabular}{|c|c|c|c|c|c|c|c|}
\hline \multirow[b]{2}{*}{$\begin{array}{l}\text { Bentonite } \\
\text { type }\end{array}$} & \multirow[b]{2}{*}{$\begin{array}{l}\text { Application } \\
\text { rate (ton/f) }\end{array}$} & \multicolumn{6}{|c|}{$2015-2016$} \\
\hline & & $\begin{array}{l}\mathrm{E} . \mathrm{C} \\
\left(\mathrm{dSm} \mathrm{m}^{-1}\right)\end{array}$ & $\begin{array}{c}\mathrm{pH} \\
(1: 2.5)\end{array}$ & $\begin{array}{l}\text { C.E.C } \\
\mathrm{cmol} / \mathrm{kg} \text { soil }\end{array}$ & $\begin{array}{c}\text { Organic } \\
\text { matter } \\
(\%)\end{array}$ & $\begin{array}{l}\text { Saturation } \\
\text { percent } \\
(\%)\end{array}$ & $\begin{array}{l}\text { Field } \\
\text { capacity } \\
(\%)\end{array}$ \\
\hline \multirow{4}{*}{ Black } & 0 & 1.65 & 7.81 & 4.20 & 0.25 & 8.90 & 38.50 \\
\hline & 5 & 2.21 & 7.85 & 4.90 & 0.32 & 11.10 & 49.30 \\
\hline & 10 & 2.80 & 7.91 & 5.80 & 0.33 & 12.10 & 55.20 \\
\hline & 15 & 3.10 & 7.90 & 6.30 & 0.46 & 13.80 & 59.80 \\
\hline \multicolumn{2}{|c|}{ Mean } & 2.44 & 7.87 & 5.30 & 0.34 & 11.48 & 50.70 \\
\hline \multirow{4}{*}{ Brown } & 0 & 1.75 & 7.72 & 4.10 & 0.23 & 9.20 & 40.10 \\
\hline & 5 & 2.61 & 7.79 & 4.50 & 0.29 & 10.80 & 47.20 \\
\hline & 10 & 3.10 & 7.80 & 5.30 & 0.39 & 11.60 & 54.60 \\
\hline & 15 & 3.50 & 7.81 & 5.80 & 0.41 & 14.20 & 58.90 \\
\hline \multicolumn{2}{|c|}{ Mean } & 2.74 & 7.78 & 4.93 & 0.33 & 11.45 & 50.20 \\
\hline \multirow{4}{*}{$\begin{array}{l}\text { Means of } \\
\text { rate }\end{array}$} & 0 & 1.70 & 7.77 & 4.15 & 0.24 & 9.05 & 39.30 \\
\hline & 5 & 2.41 & 7.82 & 4.70 & 0.31 & 10.95 & 48.25 \\
\hline & 10 & 2.95 & 7.86 & 5.55 & 0.36 & 11.85 & 54.90 \\
\hline & 15 & 3.30 & 7.86 & 6.05 & 0.44 & 14.00 & 59.35 \\
\hline \multirow{3}{*}{ L.S.D $D_{0.05}$} & Type & n.s & n.s & 0.20 & n.s & n.s & n.s \\
\hline & Rate & 0.20 & n.s & 0.30 & 0.04 & 0.72 & 3.10 \\
\hline & Type*Rate & n.s & n.s & 0.31 & 0.03 & n.s & n.s \\
\hline
\end{tabular}

\section{REFERENCES}

A.O.A.C. (1990). Official Methods of Analysis. $15^{\text {th }}$ ed. Association of Official Chemists, Washington, DC., U.S.A.

Abdel-Nasser, G., A.M. A. Omran, A.M. Falatah, A. S. Stato and A.R. Al-Harb (2007). Impact of natural conditioners on water retention, infiltration and evaporation characterstics of sandy soil. J. of Applied Sci. 7(13): 1699-1708.

Aghdak, P., Mobil ., A. II. Khoshgoftamanesh and F. Shakeri (2010). Effect of adding bentonite to different substrates on vegetative growth and yield of snap bean (Phaseulus vulgaris L.). J. of Sci. and Tech. of Greenhouse Culture.
Ali, A.H., M. N. Abdel-Mouty and A.M. Shaheen (2004). Effect of bio-nitrogen, organic and inorganic (Allium sativum L.) Plant Egypt J. Appli. Sci.,16(3): 173-186.

Anas, A.W., M. I. Abdel El-Ati and A.B. Mohamed (2009). Integrated input soil and water management in maximizing peanut crop under the eastern drough front desert outskih of El Fayoum governorate, Egypt. J. Agric. and \& Biol. Sci., 5(1) 1-15.

Black, C.A. (1965). Methods of soil analysis (two parts I and II) Aner. Soc. Agron. Unc. Publisher. USA.

Chapman, H. D. and P. F. Pratt (1982). Methods of plant analysis. I. Methods of Analysis for Soil, Plant and Water. 
Chapman, Publisher, Riversid, California U.S.A.

Chittleborough, D. and J. Churchman (2005). Effects upon carbon sequestration of adding reactive clay to soils. 7-8 in Geoscience Honors projects 2013. The university Adilaide. Australia Gan, Y. 2005. General situation of use non-metallic minerals as carries of chemical fertilizers. J. of Chem. Ferti. Indust. Issue, PP: 5.

Churchman, G.J., A.D. Nobel and D. J. Chitteborough (2012). Addition of clay and clay minerals to enhance the sequestration of carbon in soils. Australian, P.P. 117-120.

Cottenie, A., M. Verloo, L. Kickens, G. Velgh and R. Camerlgnck (1982). Chemical Analysis of Plant Soils Laboratory of Analytical and Agrochemistry. State University, Ghent, Belgium.

El-Sherif, A.F. (1987). Project research on the improvement sandy soil. Methods and economical viow. Final Report . ARST, Cairo, Egypt, PP: 1982.

FAOSTAT, (2011). Food and agriculture organization on the United Nation, http: // faostat, fao.org/statistic.

Fernandez-Nava, Y. M. Ulmanu, I. Anger, E. Maranon and L. Castrillon (2011). Use of granular bentonite the removal of merurg (IT), cadmium (IT) and lead (II) from aqueous solution. Water Air Poll., 212: 239-249.

Hossam, A.Z.A. and Abdel Wahab M. Mahmoud (2013). The combined effect of bentonite and natural zeolite on sandy soil properties and productivity of some crops. Topcls. J. Agric. Res., 1(3)23: 2228.

Jana, D.and S. Kabi (2012). Effect of gromon Sulphur bentonite Sulphur pastilles on yield and nutrient uptakeby hybrid ric-potato-green gram cropping system in an inceptisol. Int. Res. J. Agric. Soil Sci.2(5): 179-187.

Noble, A.D., R.S. Pemmg de Vries, F.W.T. Hartman and M.J. Webb (2004). Enhancing the agronomic productivity of degraded soil in North -Cost Thailand through based interventions. In V. Serg, E. Crawell, S. Fulai and K. Fscer eds., Water and agricultural proceeding No. 116, Canberra, PP, 147-160.

Page, A.L. (1982). Methods of soil analysis. Part 2- chemical and microbiological properties second Edition Ajner. Soc. Of Argon. Madison, Wisconsin, USA.

Qu, G., A. de Varennes and C.C unha Queda (2009). Remendation of nine soil with insolubalepolyacrylate polymers enhances soil quality and plant growth. Soil use Manage. 24: 350-356.

Reguieg, H.A.Y., A. Latigui, T. Nourig and L. Bessafi (2012). Effect of salt stress and bentonite on the germination and proline content of Visiafaba L. Plant Var. Semillavioleta and Reine mora. Am. J. of Plant Physiol. 7(5): 212-219.

Shaheen, A.M., Fatma A. Rizk, E.H. Abd ElSamad and Soad M. El-Ashry (2013). Effect of nitrogen fertilizer and soil conditioner on the productivity of potato plants grown under sandy soil conditions. J. Applied Sci. Res. 9(3): 1774- 1781.

Sitthaphanit, S., W. Richard and V. Limpinuntan (2010). Effect of clayamendmentson nitrogen leaching and forms in sandy soil. World Congress of soil.

Tawiq, A. J. (2009). Improvement of sandy soil properties by using bentonite. Kofa $\mathrm{J}$. of Eng. 1(1): 29-39.

Yassad, H. R. and M. Belkhaodja (2007). The effect of sandy soils in Algeria.

Youssef, B.D. (2013). Effect of bentonite and zeolite ores on potato crop (Solanumtubersum L.)under north Sini conditions. J. Plant Production, Mansoura Univ. 14(12): 1843-1856.

Zelalem, A.T., Tekglign and D. Nigussie (2009). Response of potato (solanumtubersum L.) to different rates of nitrogen and phosphorus fertilization on vertisols at Debra Berham, in the central high lands of Ethiopia. African J. Plant Sci., 3(2): 16-24. 


\section{تأثير إضافة البنتونيث على كل من النمو الخضرى والمحصول وجودته وخواص الأرض الرملية}

رمضان عبد العاطى محمد(1) ، رشاد عبد المنعم درار(1) ، محمد محمد عبد الغنى(2)

$$
\text { (1) معهد بحوث البساتين - مركز البحوث الزراعية - الجيزة }
$$

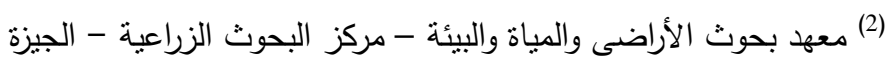

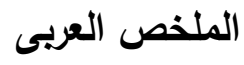

أققيمت تجربتين حقليتين خلال الموسم الشتوى 2104- 2015 ، 2015- 2016 في محطة البحوث الزراعية التابعة

لمعهد البساتين بمعل مبارك لدراسة نأثير إضافة نوعين - البنتونيت (أسود وبنى) ومعدلات إضافتهم (صفر - 5 - 10 -

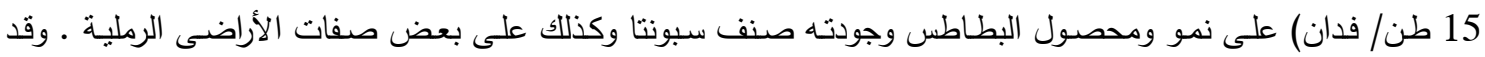

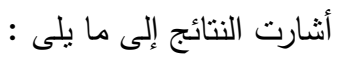
- أدى إضافة البنتونيت سواء الأسود أو البنى إلى زيادة معنوية في النمو الخضرى للبطاطس (طول النبات ، عدد الأفرع ،

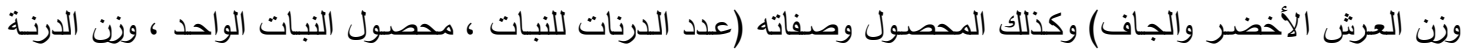
الواحدة ، ومحصول الدرنات/ فدان) مقارنه بالكنترول ، وكانت أعلى قيم متحصل عليها عند إضافة 15 طن/ فدان من كلا

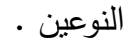
- كان هناك فرق معنوى بين البنتونيت الأسـود والبنى حيث أدى إضـافة البنتونيت الأسود إلى أعلى قيم الصفات النمو الخضرى والمحصول وصفاته .

- أدى إضافة كلا النوعين من البنتونيت الى زيادة معنوية فى محتوى الأوراق من النيتروجين والفسفور والبوتاسيوم وكذلك

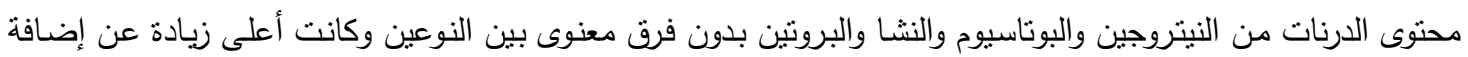
15 طن/ فدان. - أدى إضـافة البنتونيت من كلا النوعين إلى زيادة في ملوحة التربـة ، والسعة التبادلية الكاتيونية والمادة العضوية والسعة الحقلية والتشبع وازدادت هذه الصفات بزيادة دعدل الإضافة ، وكان هناك فرق معنوى بين البنتونيت الأسود والبنى حيث

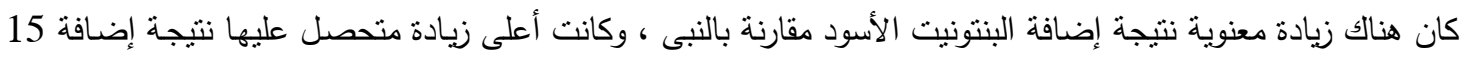
طن/ فدان بنتونيت الأسود . 